\title{
SHORT REPORT \\ Role of Chlamydia trachomatis and emerging Chlamydia-related bacteria in ectopic pregnancy in Vietnam
}

\author{
S. HORNUNG ${ }^{1}$, B. C. THUONG ${ }^{2}$, J. GYGER ${ }^{1}$, C. KEBBI-BEGHDADI ${ }^{3}$, \\ S. VASILEVSK $Y^{1}$, G. GREUB ${ }^{3,4}$ AND D. BAUD ${ }^{1 *}$ \\ ${ }^{1}$ Materno-fetal and Obstetrics Research Unit, Department of Obstetrics and Gynaecology, Maternity, University \\ Hospital, Lausanne, Switzerland \\ ${ }^{2}$ Tu Du Hospital, 284 Cong Quynh Pham Ngu Lao Ward, District 1, Ho Chi Minh City, Vietnam \\ ${ }^{3}$ Center for Research on Intracellular Bacteria, Institute of Microbiology, Faculty of Biology and Medicine, \\ University of Lausanne and University Hospital, Lausanne, Switzerland \\ ${ }^{4}$ Infectious Disease Service, University Hospital, Lausanne, Switzerland
}

Received 29 August 2014; Final revision 13 November 2014; Accepted 30 November 2014; first published online 29 December 2014

\section{SUMMARY}

In this case-control study, we investigated the seroprevalence and molecular evidence of Chlamydia trachomatis and Waddlia chondrophila in ectopic pregnancies (EP) and uneventful control pregnancies in 343 women from Vietnam. Whereas presence of C. trachomatis IgG was strongly associated with EP [adjusted odds ratio (aOR) 5.41, 95\% confidence interval (CI) 2.58-11.32], its DNA remained undetected in all tubal lesions. We confirmed an independent association between antibodies against Waddlia and previous miscarriage (aOR 1.87, 95\% CI 1.02-3.42). Further investigations are needed to understand the clinical significance of Waddlia's high seroprevalence $(25.9 \%$ in control pregnancies) in this urban population.

Key words: Adverse pregnancy outcome, Chlamydia-related bacteria, ectopic pregnancy, genital tract infection, intracellular bacteria.

Chlamydiae are obligate intracellular bacteria belonging to the order Chlamydiales [1]. Chlamydia trachomatis is the most common bacterial cause of sexually transmitted infections worldwide [2]. In women, $90 \%$ of $C$. trachomatis infections remain asymptomatic. However, if left untreated, chlamydial infection can lead to scarring of uterine tubes, pelvic inflammatory disease (PID), ectopic pregnancy (EP) and adverse pregnancy outcomes [2,3]. C. trachomatis induced pathogenesis is largely a result

\footnotetext{
* Author for correspondence: D. Baud, MD, PhD, Materno-fetal \& Obstetrics Research Unit, Department of Obstetrics and Gynecology, University Hospital, Centre Hospitalier Universitaire Vaudois (CHUV), 1011 Lausanne, Switzerland. (Email: david.baud@chuv.ch)
}

of chronic immunopathological reactions, most likely caused by persistent infections [3].

Waddlia chondrophila, a Chlamydia-related bacterium, has recently been associated with both animal and human adverse pregnancy outcomes, such as miscarriage $[2,4-6]$. Its mode of transmission and pathogenesis remains to be explored.

Since several Chlamydia spp. and Chlamydia-related bacteria colonize the cervico-vaginal mucosa [5-7], which may lead to tubal scarring and have been associated with adverse pregnancy outcomes in humans, we thus investigated their role in EPs. EP, a condition in which a fertilized egg settles and grows in a location other than the inner lining of the uterus, occurs in $2 \%$ of all pregnancies and remains the leading cause of pregnancy-related death in the first trimester of gestation $[8,9]$. 
Table 1. Sociodemographical data and serologies according to pregnancy outcome

\begin{tabular}{lllr}
\hline \hline Characteristics & Control $(n=166)$ & Ectopic pregnancy $(n=177)$ & $P$ value \\
\hline Age, years $( \pm$ s.D. & $28 \pm 5 \cdot 2$ & $30 \cdot 3 \pm 6 \cdot 4$ & $0 \cdot 0003$ \\
$\quad \geqslant 40$ years & $6(3 \cdot 6 \%)$ & $17(9 \cdot 6 \%)$ & $0 \cdot 031$ \\
Nulliparity & $111(66 \cdot 9 \%)$ & $72(40 \cdot 7 \%)$ & $<0 \cdot 001$ \\
Comorbidity & $19(11 \cdot 5 \%)$ & $7(4 \%)$ & $0 \cdot 013$ \\
Pets at home & $53(31 \cdot 93 \%)$ & $54(30 \cdot 51 \%)$ & $0 \cdot 777$ \\
Lifetime sexual partners $(\geqslant 2)$ & $2(1 \cdot 2 \%)$ & $12(6 \cdot 8 \%)$ & $0 \cdot 012$ \\
Chlamydia trachomatis ELISA* & & & \\
Negative & $153(92 \cdot 2 \%)$ & $126(71.2 \%)$ & $<0 \cdot 0001$ \\
Positive & $11(6 \cdot 6 \%)$ & $44(24.9 \%)$ & \\
Doubtful $\dagger$ & $2(1 \cdot 2 \%)$ & $7(4 \%)$ & \\
Waddlia MIF & & & $0 \cdot 04$ \\
Total Ig $\geqslant 1 / 64$ & $49(29 \cdot 5 \%)$ & $71(40.1 \%)$ & $0 \cdot 2$ \\
IgG $\geqslant 1 / 64$ & $43(25 \cdot 9 \%)$ & $57(32.2 \%)$ & 1 \\
IgM $\geqslant 1 / 32$ & $2(1 \cdot 2 \%)$ & $3(1.7 \%)$ & $0 \cdot 046$ \\
Waddlia ELISA OD & $0 \cdot 35 \pm 0 \cdot 097$ & $0 \cdot 371 \pm 0 \cdot 092$ & $0 \cdot 125$ \\
Parachlamydia IgG MIF & $10(6 \cdot 0 \%)$ & $19(10.7 \%)$ & $0 \cdot 081$ \\
Estrella IgG MIF & $21(12 \cdot 7 \%)$ & $35(19.8 \%)$ & $1 \cdot 0$ \\
Criblamydia MIF & $4(2 \cdot 4 \%)$ & $5(2.8 \%)$ & \\
\hline \hline
\end{tabular}

MIF, Microimmunofluorescence; OD, optical density.

* MOMP-R, CT pELISA (R-Biopharm, Germany)

$\dagger$ Similar $P$ values when doubtful were excluded.

A total of 343 patients were recruited at $\mathrm{Tu} \mathrm{Du}$ Hospital, Hô Chi Minh City (Vietnam). The EP group included 177 women with an EP treated by laparoscopic salpingectomy. The control group included 166 women without any history of previous EP and who experienced an uneventful pregnancy. Blood samples, fallopian tubes or placental biopsies were collected for each EP and control patient. Local ethical committees of both hospitals (clinical part in Vietnam and experimental part in Switzerland) approved the study protocol and all patients included in the study gave their written consent.

Serological status and epidemiological data were compared between patients with and without EPs, or between patients with and without Waddlia-positive serology by Pearson's $\chi^{2}$ test (or Fisher's exact test when indicated) for categorical variables. For continuous variables, medians were compared by the Wilcoxon-Mann-Whitney test. Multivariate logistic regressions were performed to identify factors independently associated with EPs and miscarriages. All statistical analyses were performed using Stata v. 13.0 (StataCorp., USA).

Sociodemographical data are presented in Table 1. All sera were tested for antibodies against $C$. trachomatis (Table 1), as described previously [1, 4, 6, 7, 10, 11]. C. trachomatis $\operatorname{IgG}$ seroprevalence was $6 \cdot 6 \%$ in the present Asian control population. Similar prevalence has been described by other studies [7, 12, 13]. C. trachomatis seroprevalence was higher for women who experienced an EP $(24.9 \%)$ than for women with an uneventful pregnancy $(6 \cdot 6 \%, P<0 \cdot 001)$.

For Waddlia and other Chlamydia-related bacteria microimmunofluorescence (MIF) tests were performed as described previously [1, 4, 6]. All immunofluorescence samples were read by two independent observers and only congruent results were considered positive. Sera that exhibited total immunoglobulin (Ig) titre $\geqslant 1: 64$ were tested for IgG and $\mathrm{IgM}$ reactivity using corresponding anti-human Fluorescein-labelled Ig (FluolineG or FluolineM, bioMérieux, France) and serial twofold dilutions of sera. Waddlia IgG and IgM positivity cut-offs were $\geqslant 1: 64$ and $\geqslant 1: 32$, respectively [1]. There was a significant association between total anti-Waddlia antibodies detected by MIF and EP $(P=0 \cdot 04)$. However, there was no statistical association with EP when anti-Waddlia IgG, or anti-Waddlia IgM, were considered. Waddlia ELISA was performed as described previously [14] and confirmed the association between Waddlia seropositivity and EP $(P=0 \cdot 046)$. Serological evidence of human exposure to other Chlamydia-related bacteria, such as Parachlamydia acanthamoebae, Estrella lausannensis and Criblamydia sequanensis were not associated 
Table 2. Patient's characteristics according to their Waddlia serological status

\begin{tabular}{|c|c|c|c|}
\hline Characteristics & $\begin{array}{l}\text { Waddlia } \operatorname{IgG} \\
\text { negative }(n=243)\end{array}$ & $\begin{array}{l}\text { Waddlia } \mathrm{IgG} \\
\text { positive }(n=100)\end{array}$ & $P$ value \\
\hline Age, years ( $( \pm$ s.D. $)$ & $28 \cdot 7 \pm 5 \cdot 7$ & $30 \cdot 3 \pm 6 \cdot 3$ & $0 \cdot 02$ \\
\hline$\geqslant 40$ years & $10(4 \cdot 1 \%)$ & $13(13 \%)$ & $0 \cdot 007$ \\
\hline Nulliparity & $137(56 \cdot 4 \%)$ & $46(46 \%)$ & $0 \cdot 08$ \\
\hline Previous miscarriage & $34(14 \%)$ & $24(24 \%)$ & $0 \cdot 005$ \\
\hline Comorbidity & $18(7 \cdot 4 \%)$ & $7(7 \%)$ & 1 \\
\hline Pets at home & $166(68 \cdot 31 \%)$ & $70(70 \%)$ & $0 \cdot 759$ \\
\hline Lifetime sexual partners $(\geqslant 2)$ & $11(4 \cdot 5 \%)$ & $3(3 \%)$ & $0 \cdot 765$ \\
\hline Chlamydia trachomatis ELISA & $37(15 \cdot 2 \%)$ & $18(18 \%)$ & $0 \cdot 513$ \\
\hline Parachlamydia IgG MIF & $19(7 \cdot 8 \%)$ & $10(10 \%)$ & $0 \cdot 525$ \\
\hline Estrella IgG MIF & $38(15 \cdot 6 \%)$ & $18(18 \%)$ & 0.63 \\
\hline Criblamydia MIF & $5(2 \cdot 1 \%)$ & $4(4 \%)$ & $0 \cdot 292$ \\
\hline
\end{tabular}

MIF, Microimmunofluorescence.

with EP (Table 1). When all variables from Table 1 were considered (stepwise logistic regression analysis), the only three independent factors associated with EP were a positive $C$. trachomatis serology [adjusted odds ratio (aOR) 5.41, 95\% confidence interval (CI) 2.58-11.31], number of sexual partners (aOR 9.34, 95\% CI 1.9544.66) and parity (aOR 2.69, 95\% CI 1.94-3.75), which are well known risk factors for EP [8,9]. Patients' characteristics according to their $C$. trachomatis serological status are given in Supplementary Table S1.

Women seropositive for Waddlia $(n=100,29 \cdot 2 \%)$ were older $(P=0.007)$ and experienced previous miscarriages more frequently $(P=0 \cdot 005)$ than Waddlianegative women (Table 2). The association between Waddlia seropositivity and miscarriage remained significant (aOR 1.87, 95\% CI 1.02-3.42) even after adjustment for age, parity, comorbidity and other serologies including C. trachomatis. There was no statistical association between Waddlia-positive serology and medical comorbidities, gynaecological complaints during pregnancy, work status, number of lifetime sexual partners or presence of pets at home.

There was no cross-reaction between Waddlia and C. trachomatis serologies, since 77 patients $(23 \cdot 1 \%)$ were positive only for Waddlia IgG and $37(11 \cdot 1 \%)$ were positive only for $C$. trachomatis IgG (Table 2). Only 18 patient $(5 \cdot 4 \%)$ were positive for both bacteria $(P=0.513)$.

Presence of Waddlia $[15,16]$ and/or $C$. trachomatis [7] DNA was tested in IgG-positive patients. DNA extraction was performed from a 2-cm piece of fallopian tube (EP) or placental (C) tissue using Wizard SV genomic DNA purification kit (Promega Corporation, USA), and a pan-Chlamydiales PCR was performed as described previously [17]. This
Pan-Chlamydiales PCR is able to detect up to five DNA copies per reaction and demonstrated similar performance compared to specific Chlamydiales PCRs. Neither the 50 fallopian tubes nor the 43 placental samples with a positive Waddlia and/or C. trachomatis serology were positive for Waddlia or C. trachomatis DNA. All 20 control patients with a negative serology (10 from the 'EP' group and 10 from the ' $\mathrm{C}$ ' group) were also negative by PCR.

In summary, our data showed a strong association between $C$. trachomatis seropositivity and EP. However, neither the fallopian tubes nor placenta of women with positive Chlamydia or Waddlia serologies demonstrated presence of respective bacteria, which has also been shown by others [12]. Moreover, IgG but not IgM antibodies were detected during EPs. Thus, these results suggest that the persistence of the bacteria is not necessary to induce tubal damage, and reinforces the role of an immunopathological process due to a previous chlamydial infection $[18,19]$. However, the physiopathology mechanism by which tubal scarring occurs without the presence of bacteria is not yet fully understood $[12,19]$.

Waddlia IgG seroprevalence in the control group $(25.9 \%)$ was higher than previously described in other asymptomatic patients: $14 \cdot 6 \%$ in Switzerland [6], and $7 \cdot 1 \%$ in London [4]. This difference could be explained as a result of higher genetic susceptibility of the Vietnamese population to Waddlia infection or greater exposure to the yet unknown source of Waddlia infection $[2,4,6]$.

Whereas our study only identified a limited association of Waddlia with EP $(P=0 \cdot 04)$, we observed a strong correlation between previous history of miscarriage and positive Waddlia serology $(P=0 \cdot 005)$. This 
was expected since Waddlia was previously reported as an abortigenic agent in both animal and human populations [2, 4-6, 19].

A major limitation of the study was the absence of data concerning other potential confounding factors for EP (i.e. other infectious agents) and miscarriage (i.e. chromosomal anomalies).

In conclusion, this study confirmed the serological association of C. trachomatis with EP [8] and of Waddlia with miscarriage [4, 6]. Moreover, we showed an association between anti-Waddlia antibodies and EP using both immunofluorescence and ELISA. Absence of $C$. trachomatis and $W$. chondrophila DNA in the fallopian tubes or placental tissues suggests that immunopathological mechanisms rather than bacterial infection are involved in EP. Further investigations are needed to understand the high prevalence of Waddlia in this Asian population and to precise its role in EP.

\section{SUPPLEMENTARY MATERIAL}

For supplementary material accompanying this paper visit http://dx.doi.org/10.1017/S0950268814003616.

\section{ACKNOWLEDGEMENTS}

We thank all the midwives and doctors who actively participated in this study at $\mathrm{Tu}$ Du Hospital. Their involvement was essential to the whole process, and they enthusiastically gave their time to provide information and samples.

This work was supported by the Department of Obstetrics and Gynecology, Maternity, Lausanne, Switzerland. This work was also partially funded by SNSF grant no. 310030- 130466 attributed to Professor G. Greub. David Baud is supported by the 'Fondation Leenaards' through the 'Bourse pour la relève académique'.

\section{DECLARATION OF INTEREST}

None.

\section{REFERENCES}

1. Corsaro D, Greub G. Pathogenic potential of novel Chlamydiae and diagnostic approaches to infections due to these obligate intracellular bacteria. Clinical Microbiology reviews 2006; 19: 283-297.

2. Baud D, Greub G. Intracellular bacteria and adverse pregnancy outcomes. Clinical Microbiology and Infection 2011; 17: 1312-1322.
3. Darville T, Hiltke TJ. Pathogenesis of genital tract disease due to Chlamydia trachomatis. Journal of Infectious Diseases 2010; 201 (Suppl. 2): S114-S1125.

4. Baud D, et al. Waddlia chondrophila, a potential agent of human fetal death. Emerging Infectious Diseases 2007; 13: 1239-1243.

5. Baud D, et al. Waddlia chondrophila: from bovine abortion to human miscarriage. Clinical Infectious Diseases 2011; 52: 1469-1471.

6. Baud D, et al. Role of Waddlia chondrophila placental infection in miscarriage. Emerging Infectious Diseases 2014; 20: 460-464.

7. Baud D, et al. Role of Chlamydia trachomatis in miscarriage. Emerging Infectious Diseases 2011; 17: 1630-1635.

8. Rana P, et al. Ectopic pregnancy: a review. Archives of Gynecology and Obstetrics 2013; 288: 747-757.

9. Farquhar CM. Ectopic pregnancy. Lancet 2005; 366: 583-591.

10. Baud D, et al. Performance of an automated multiplex immunofluorescence assay for detection of Chlamydia trachomatis immunoglobulin G. Diagnostic Microbiology and Infectious Disease 2014; 78: 217-219.

11. Baud D, Regan L, Greub G. Comparison of five commercial serological tests for the detection of antiChlamydia trachomatis antibodies. European Journal of Clinical Microbiology \& Infectious Diseases 2010; 29: 669-675.

12. Shaw JL, Horne AW. The paracrinology of tubal ectopic pregnancy. Molecular and Cellular Endocrinology 2012; 358: 216-222.

13. Yongjun T, et al. The prevalence of sexually transmitted and other lower reproductive tract infections among rural women in Sichuan Province, China. Southeast Asian Journal of Tropical Medicine and Public Health 2009; 40: 1038-1047.

14. Lienard $\mathbf{J}$, et al. Undressing of Waddlia chondrophila to enrich its outer membrane proteins to develop a new species-specific ELISA. New Microbes and New Infections 2014; 2: 13-24.

15. Goy G, et al. Development of a real-time PCR for the specific detection of Waddlia chondrophila in clinical samples. European Journal of Clinical Microbiology \& Infectious Diseases 2009; 28: 1483-1486.

16. Lienard $\mathbf{J}$, et al. Development of a new chlamydialesspecific real-time PCR and its dapplication to respiratory clinical samples. Journal of Clinical Microbiology 2011; 49: 2637-2642.

17. Croxatto A, et al. Presence of Chlamydiales DNA in ticks and fleas suggests that ticks are carriers of Chlamydiae. Ticks and Tick-borne Diseases 2014; 5: 359-365.

18. Witkin SS, Ledger WJ. Antibodies to Chlamydia trachomatis in sera of women with recurrent spontaneous abortions. American Journal of Obstetrics and Gynecolgy 1992; 167: 135-139.

19. Baud D, Regan L, Greub G. Emerging role of Chlamydia and Chlamydia-like organisms in adverse pregnancy outcomes. Current Opinion in Infectious Diseases 2008; 21: 70-76. 